\title{
Regional Innovation Climate: Definition and Analysis
}

\author{
Alexandra Egorova*, Artyom Uzhegov \\ Department of Economic Theory and Regional Development, Chelyabinsk State University, Chelyabinsk 456313, Russia \\ *Corresponding author. Email: Aleksandra_csu@mail.ru
}

\begin{abstract}
In modern conditions, when Industry 4.0 sets the development trend, the competitiveness of countries in the world market will be determined by their innovative potential. Currently, for the Russian Federation, the regions play a key role in shaping a new innovation paradigm in the country's development. The article considers the approaches of domestic and foreign scientists to the definition of innovative development of the region, identifies the strengths and weaknesses of these approaches, based on previous experience of scientists, the author's approach to determining the innovative climate in the region is proposed. Based on statistical data, the authors analyzed the current state of the innovation climate in the proposed investment and innovation direction, highlighted the main trends and based on this, conclusions are drawn and recommendations are made.
\end{abstract}

Keywords: innovation climate, innovations, region, investments

\section{INTRODUCTION}

We live in an era of global technological progress and are witnessing fundamental changes that are occurring in all areas of the economy. The new paradigm, caused by fundamental changes in the production and development of countries, is called Industry 4.0, and now it is it that affects the vector of development of states. Ilya Shpurov [1] - Vice-President of the International Congress of Industrialists and Entrepreneurs, member of the Council for Engineering and Industrial Design at the Ministry of Industry and Trade of Russia, notes that Industry 4.0 is not a new technology, it is a fundamentally new approach to determining the properties of all human things, and their methods production.

The formation of Industry 4.0 leads to the need to ensure the proper level of innovative potential of the country in order to have a competitive advantage in the global market.

The relevance of the innovative development of regional economies is dictated by both an internal factor (balanced development of territories) and an external factor (competitiveness of the country on the world market). In the face of declining oil and gas prices, the instability of stock markets, the innovative development of the regions is important in order to form the country's innovative potential.

\section{THEORETICAL ASPECTS}

An important theoretical basis of the study is the work of domestic and foreign scientists, so the issues of stimulating the innovative regional economy are addressed by:
Deryabin [2], Ketova [3], Kirpanev [4], Kushnikov [5], Izyumova [6].

It should be noted that the majority of authors in matters of stimulating the innovative development of the region prefer the development of research institutions, attracting investment and institutional factors. So, Shelepov [7], notes that the intensification of innovative activity requires, on the one hand, public administration and coordination of actions of all its entities, on the other hand, independent efforts to integrate all those interested in implementing innovations, attracting investments, creating conditions contributing to the innovation process.

In turn, Golova et al. [8] note that one of the key factors for increasing innovative activity is the creation of conditions for innovative entrepreneurship, the adoption of government measures to limit monopoly and create legal prerequisites for the establishment of fundamental new enterprises.

Turning to the experience of foreign colleagues, it should be noted the studies of scientists from South Korea, such as Park [9], and his colleagues involved in the study of innovation clusters Hu [10], Khan [11], and Odai [12].

Studies aimed at examining the essence of innovation were carried out by: Braudel [13], Schumpeter [14], Kuznets [15], Lundvall [16], Metcalf [17], Nelson [18], Freeman [19], Porter [20].

Next, we consider the approaches of domestic authors to the problems of innovative development of regions.

The following problems are devoted to the problems of the innovative development of the regions: Kochergina [21], Kiseleva et al. [22], Avilova [23], Beketova [24], Belova et al. [25], Glazyev et al. [26], Khmeleva [27], Ivanova [28].

Khmeleva, in his work «Innovation processes in the regions of Russia» referring to Tyukavkina et al. [29] notes that the traditionally applied systematic approach to 
the development of innovative activity does not fully justify itself due to the focus of researchers on the formation of a complex of elements that form the innovative system. The author notes that in modern conditions it will be more rational to apply the process approach to the development of innovation in the region, and suggests that it be based on the development of foreign scientists, namely the theory of open innovation [30] and the three-sector innovation economy model [31]. Ischenko-Padukova et al. [32], note that the specific elements of the innovation dynamics of the Russian regions are its uneven nature, insufficient funding from the state and business of innovative initiatives, and a complex institutional mechanism for the commercialization and implementation of innovations. This state of affairs requires certain regional policy directions to achieve the goals of innovative growth: developing special mechanisms for implementing effective forms of regional regulation of innovative activity, developing innovative infrastructure in the regions, creating tools for the largescale involvement of regional small and medium-sized businesses, as well as investments from all sources, including foreign.

Thus, to summarize the above, it is safe to say that most authors, despite differences in approaches, highlight the following problems in the development of innovation in the regions:

$-\quad$ development of innovative infrastructure;
$-\quad$ research and development;
$-\quad$ involvement and stimulation of business in
research and development;
$-\quad$ institutional aspects of the introduction and
development of innovations;
$-\quad$ attraction of investments;
$-\quad$ interaction with regional authorities in order to
create an innovative economy.
In our understanding, the development of innovations should be built in a comprehensive manner, where each of the elements of the system creates a synergistic effect that affects the development of innovations in the region.

Thus, in order to consider innovative development in a comprehensive manner, taking into account the interconnections of the constituent elements, it is advisable to turn to such a concept as the innovative climate of the region. The concept of an innovative climate is often found in domestic literature as applied directly to an enterprise. So in a number of works by such authors as: Tkach [33], Chentsova [34], Volkova [35], Artyuhova [36], Tolstukhina [37] - the innovative climate is considered as the external environment in the activities of enterprises, from which it can be inferred that the innovative climate in relation to the region is its internal environment.

The following scientists were directly involved in the consideration of the innovation climate in the region: Terebova [38], Sokolova [39], Belyaeva [40], Akmaeva [41], Vidyaev [42], Golova [43].

Note that in domestic science there is no well-established definition of the innovation climate in the region. Most scientists characterize the innovation climate as the external environment of the organization, and as applied to the region, they imply some activities that positively affect innovative development. So, in the work «Assessment of the innovative climate in the region» Sokolova et al., innovative climate means a complex of economic, organizational, social, political, historical and cultural conditions for the implementation of innovative activities and innovative entrepreneurship. Vyacheslavov [44] in turn, by the innovative climate of the region means the level of favorableness of the existing scientific, technological and socio-economic conditions for the development of innovative activity and the reproduction of innovative processes

In this regard, it is advisable to formulate the author's definition of the innovation climate in relation to the region. The author's definition is as follows: this is a set of investment, institutional, and managerial measures that form an interconnected system aimed at stimulating the development of innovations in the region. It is advisable to consider the approach to the formation of an innovative climate in the region through the following areas:

$\begin{array}{ll}\text { 1. } & \text { Investment direction. } \\ \text { 2. } & \text { Institutional direction. } \\ \text { 3. } & \text { Research direction. } \\ \text { 4. } & \text { Project direction. }\end{array}$

\section{ANALYSIS}

In the Russian Federation, the innovative development path is defined as one of the priority areas in ensuring the country's competitive advantages. The transition to an innovative type of development of the national economy is reflected in many government documents. After analyzing the target indicators for the implementation of the Strategy for Innovative Development of the Russian Federation for the period up to 2020 [45], (approved by Order of the Government of the Russian Federation of December 8, 2011 No. 2227-p), we can conclude that most of the indicators responsible for innovative development in recent years show negative dynamics

To assess the level of innovative development of the region, we propose to consider the dynamics of indicators in the context of investment and innovation:

The investment and innovation direction is of key importance in the development of the region and the formation of an innovative climate. It is important to note that investment and innovation play a key role in shaping the economic potential of the region, creating high-tech industries, new products and services, attracting investments, creating new jobs - all this has a beneficial effect on the economic development of the region and its innovative climate.

As a rule, to create a favorable innovation climate, large investments are required in promising innovative projects, so it makes sense to consider these two areas as a single direction.

The innovation sphere is closely connected with the investment sphere and is primarily aimed at developing 
innovative directions in the region's activities - the creation of technology parks, the interaction of higher education institutions and business representatives in order to provide the region with new inventions and technologies.

The main goal of the investment and innovation direction is to create a favorable innovation climate in the region, which consists in a large number of attracted domestic and foreign investments, the creation of innovative industries and industrial clusters.

To conduct an analysis of the investment and innovation direction, we turn to table 1 and table 2 .

Table 1 The Dynamics of the main indicators in the investment sector

\begin{tabular}{|c|c|c|c|c|c|c|c|}
\hline \multirow{2}{*}{ Indicator } & \multicolumn{4}{|c|}{ Year } & \multicolumn{3}{|c|}{ Growthrate, \% } \\
\hline & 2016 & 2017 & 2018 & 2019 & $2017 / 2016$ & 2018/2017 & 2019/2018 \\
\hline $\begin{array}{c}\text { Investments in fixed } \\
\text { assets, total, million rubles }\end{array}$ & $\begin{array}{c}198 \\
289,0\end{array}$ & 198990,0 & 254993,0 & $\begin{array}{c}195 \\
589,0\end{array}$ & 100,4 & 128,1 & 76,7 \\
\hline $\begin{array}{c}\text { Investments perperson, } \\
\text { rubles }\end{array}$ & 56629,0 & 56892,0 & 73 181,0 & $\begin{array}{c}55 \\
783,0\end{array}$ & 100,5 & 128,6 & 76,2 \\
\hline $\begin{array}{l}\text { Investments in fixed assets } \\
\text { from abroad }\end{array}$ & - & - & - & - & - & - & - \\
\hline $\begin{array}{l}\text { Investments in fixed assets } \\
\text { from the federal budget, } \\
\text { million rubles }\end{array}$ & 12974,0 & 10045,0 & 11 117,0 & 8 187,0 & 77,4 & 110,7 & 73,6 \\
\hline $\begin{array}{l}\text { Investments in non- } \\
\text { financial assets million } \\
\text { rubles }\end{array}$ & $\begin{array}{c}144 \\
167,0\end{array}$ & 146 195,0 & 195795,0 & $\begin{array}{c}143 \\
311,0\end{array}$ & 101,4 & 133,9 & 73,2 \\
\hline $\begin{array}{l}\text { Gross regional product by } \\
\text { region, million rubles }\end{array}$ & $\begin{array}{l}1271 \\
133,0 \\
\end{array}$ & $\begin{array}{l}1348 \\
564,0 \\
\end{array}$ & $\begin{array}{l}1505 \\
662,0 \\
\end{array}$ & - & 106,1 & 111,6 & - \\
\hline $\begin{array}{l}\text { Volume of investments in } \\
\text { fixed assets,\% of GRP }\end{array}$ & 15,6 & 14,8 & 16,9 & - & 94,6 & 114,8 & - \\
\hline $\begin{array}{l}\text { The volume of foreign } \\
\text { investment in the regional } \\
\text { economy, million rubles }\end{array}$ & 33840,0 & 20922,0 & - & - & 61,8 & - & - \\
\hline
\end{tabular}

One of the key indicators in assessing the investment sphere is the indicator of investments in fixed assets, as can be seen from table 1 , this indicator shows a positive trend in 2018, but again returns to the same values in 2016-2017 by 2019. Thus, we can observe the negative dynamics in the first indicator. We observe a similar situation in the dynamics of the per capita investment rate. Investments in fixed assets of the Chelyabinsk region are mainly carried out at the expense of own funds. It is difficult to estimate the share of investments in fixed assets from abroad, since this statistic is not available in the official statistics of the Territorial Authority of the Federal State Statistics Service for the Chelyabinsk Region.

It should be noted that the indicator of investments in fixed assets from the federal budget also shows negative dynamics, which indicates a general negative trend.

An important indicator of assessing the financial security of a region is the dynamics of investments in non-financial assets, since many enterprises have an acute question of updating the technical park of the enterprise. Many enterprises have a situation of full or partial depreciation of fixed assets. The Ural Federal District takes the first place in Russia in terms of depreciation of fixed assets of enterprises - this was announced by Nikolai Vinnichenko, plenipotentiary of the President of the Russian Federation in the Urals Federal District, at a district meeting held in Chelyabinsk on January 24, 2020 with heads of major enterprises. According to Nikolai Vinnichenko [46], the greatest degree of deterioration of machines, equipment and vehicles is characteristic of those industries and enterprises that make the main contribution to the increase in gross product.

The dynamics of investments in non-financial assets shows a noticeable increase, only in 2018, but by 2019 it returns to indicators close to 2016-2017. This indicator signals a negative trend in the competitiveness of regional enterprises, their technical equipment, this negative dynamics has a bad effect on the safety of workers and directly affects the competitiveness of enterprise products. Analyzing the state of investment activity of the Chelyabinsk region, attention should be paid to the indicator of the volume of investments in fixed assets in\% of GRP. On September 29, 2018, the Government of the Russian Federation approved the Main Activities of the Government of the Russian Federation for the period up to 2024. One of the goals set forth in this document is the Russian Federation becoming one of the five largest economies in the world, ensuring economic growth rates above the world while maintaining macroeconomic stability, including inflation, at a level not exceeding 4 percent.

As one of the mechanisms for realizing this goal, it is envisaged to improve the quality of investments in fixed assets and an increase in their volume to 25 percent of the share in GDP [47].

Based on the declared at the federal level goal of increasing GDP, the calculation method establishes the 
need for the presence at the regional level of a ratio of investment in fixed assets to GRP of at least 25 percent.

Thus, it can be stated that even with the positive dynamics of the volume of investments in fixed assets to GRP, the indicator for 2016-2018 is far from the normative value.

Regarding foreign investments in the economy of the Chelyabinsk region for the analyzed period, we can note a significant decrease in this indicator in 2017 compared to the previous year and this decrease amounted to 38.2 percent. It's too early to talk about the negative trend, as data for 2018 and 2019 are not available.

Currently, the Chelyabinsk region has taken a course on the development of innovation:

So in the Chelyabinsk region, the Fund for the Promotion of the Development of Small Forms of Enterprises in the Scientific and Technical Field - the Fund for the Promotion of Innovations, which on a competitive basis provides financing of innovative projects.

Financing is provided by the Fund in the form of a free and non-refundable cash grant allocated on a competitive basis for research and development, as well as the production of innovative products under a number of programs.
«UMNIK» -500 thousand rubles for a period of 2 years; «START» - from 2 to 5 million rubles (depending on the stage of the project);

«COMMERCIALIZATION» - up to 20 million rubles for a period of 1 year [48].

The following innovative infrastructure is present in the region:

1. Business incubators of the Chelyabinsk region (Chelyabinsk, Magnitogorsk, Ozersk, Snezhinsk).

2. IT park (support for startups in the IT field).

3. Boiling point - Chelyabinsk (activities within the framework of the National Technological Initiative (STI) in the Chelyabinsk region).

4. The Foundation for the Development of Internet Initiatives Ural (financing startups and assisting entrepreneurs in the development of Internet projects).

5. Regional engineering center - Chelyabinsk region.

6. South Ural Chamber of Commerce and Industry, Intellectual Property Center.

Let us turn to indicators characterizing the innovative development of the Chelyabinsk region. The data are presented in table 2 .

Table 2 The dynamics of indicators in the innovation sphere

\begin{tabular}{|c|c|c|c|c|c|}
\hline \multirow{2}{*}{ Indicator } & \multicolumn{3}{|c|}{ Year } & \multicolumn{2}{|c|}{ Growthrate, \% } \\
\hline & 2016 & 2017 & 2018 & $2017 / 2016$ & 2018/2017 \\
\hline $\begin{array}{c}\text { The proportion of organizations } \\
\text { implementing technological } \\
\text { innovations,\% }\end{array}$ & 27,0 & 25,8 & 6,2 & 95,4 & 24,0 \\
\hline $\begin{array}{c}\text { Innovative activity of organizations, } \\
\%\end{array}$ & 7,0 & 17,3 & 16,6 & 247,0 & 96,2 \\
\hline $\begin{array}{l}\text { The volume of innovative goods, } \\
\text { works, services, million rubles }\end{array}$ & 1373457,1 & 1437085,8 & 1661691,1 & 104,6 & 115,6 \\
\hline $\begin{array}{c}\text { Costs of technological innovation of } \\
\text { organizations, million rubles }\end{array}$ & 29814,5 & 21614,5 & 28327,0 & 72,5 & 131,1 \\
\hline $\begin{array}{l}\text { Developed advanced manufacturing } \\
\text { technologies, units }\end{array}$ & 121,0 & 122,0 & 145,0 & 100,8 & 118,9 \\
\hline $\begin{array}{c}\text { Used advanced manufacturing } \\
\text { technologies, units }\end{array}$ & 7000,0 & 7306,0 & 7358,0 & 104,4 & 100,7 \\
\hline $\begin{array}{l}\text { The number of researchers } \\
\text { performing research and } \\
\text { development, per 10,000 employed } \\
\text { in the economy }\end{array}$ & 39,0 & 41,3 & 41,7 & 105,9 & 101,0 \\
\hline Use of intellectual property, units & 664,0 & 710,0 & 939,0 & 106,9 & 132,3 \\
\hline \multicolumn{6}{|l|}{ Including: } \\
\hline Inventions & 462,0 & 453,0 & 659,0 & & \\
\hline Utility models & 102,0 & 123,0 & 130,0 & & \\
\hline Industrial designs & 46,0 & 40,0 & 36,0 & & \\
\hline Data bases & & 4,0 & 2,0 & & \\
\hline Computer programs & 54,0 & 90,0 & 112,0 & & \\
\hline
\end{tabular}

After analyzing the dynamics of indicators in a general way, we can conclude that the largest innovative activity of organizations was recorded in 2017, as well as the proportion of organizations implementing technological innovations. The remaining indicators show a slight positive trend, which indicates a general positive vector in the innovative direction.
According to the results of 2019, 64 professional educational organizations carry out educational activities in the Chelyabinsk region.

The system of higher education in the Chelyabinsk region is represented by 28 educational institutions of higher education, while:

- $\quad$ non-governmental sector includes 12 educational organizations of higher education; 
- $\quad$ subordinate to the Ministry of Culture of the Chelyabinsk region, are two educational organizations of higher education - «South Ural State Institute of Arts named after P.I. Tchaikovsky» and «Magnitogorsk State Conservatory (Academy) named. M.I. Glinka»;

other educational institutions of higher education - of federal subordination, are represented either by parent organizations (20 in total), or their branches.

South Ural State University is a participant in the 5-100 project, a state program to support leading Russian universities aimed at increasing the competitiveness of Russian education in the global educational and scientific space. «Magnitogorsk State Technical University named after G.I. Nosova» was among the 22 core universities. The project to create support universities is aimed at the formation in the regions of scientific and educational centers, focused primarily on the needs of the regional economy and the regional labor market. The total number of students in educational institutions of higher education is 110,403 people.

As part of the interaction of industrial enterprises with educational organizations of higher education, students' educational and production practices were organized. To ensure practice-oriented training, taking into account the requirements of real production, universities in the region that train engineering personnel enter into agreements with enterprises by employers, and basic departments are created.

For example, South Ural State University and Magnitogorsk State Technical University, G.I. Nosov created the basic department of the Foundry-Mechanical Plant LLC; OJSC «Plant Magnesite»; LLC Elektromashina; Miass Engineering Plant LLC; JSC «Konar»; PG Metran.

Work is being carried out with industrial enterprises on the implementation of joint projects and grants aimed at nanotechnology. We considered a detailed model of interaction between higher education institutions, business, and the region in the article «Creating an innovative climate in the region using a model of interaction between higher education institutions and business» [49].

In the framework of cooperation with NPO Android Technique, Magnitogorsk State Technical University provides targeted training for specialists in the following areas: Informatics and Computing, Mechatronics and Robotics, Control in Technical Systems, Electronics and Microelectronics, Ground-based Transportation technological complexes.

It is worth noting the expansion of the use of digital technologies in education. Higher education programs in the field of information technology are implemented by 6 educational institutions of higher education.

Six new master's programs have been developed by South Ural State University with the aim of training unique specialists who will have competencies in the field of economics, management, and information technology: "Accounting, analysis and control in the corporate digital environment», «Economics SmartCity», «Strategic and Corporate Governance in the Digital Economy».

At the same time, the practice of creating and developing a network of engineering centers based on the leading universities of the Chelyabinsk region (MSTU, SUSU, CSU) continues.

Collaboration is ongoing with Siemens, SMM-Group, Bosch, Fortum, Konar. A major achievement is the signing of an agreement to open the Samsung IoT Academy program and a unique training laboratory for studying Internet of Things (IoT - InternetofThings) at the Higher School of Electronics and Computer Science.

As a consequence of all the above measures, the share of graduates of the higher education system of the region employed in their specialty in 2019 amounted to 80\%.

In order to create favorable conditions for the growth of regional scientific and technological development in priority areas of science development, including those aimed at stimulating, attracting and retaining graduates of educational institutions of higher education, talented youth in the Chelyabinsk region in 2019, a number of measures were taken:

Collaboration has been established with the Russian Foundation for Basic Research, in the framework of which the implementation of competitive measures to support fundamental scientific research of scientists of the region from 2020 is envisaged

As part of the Cooperation Agreement between the Government of the Sverdlovsk Region, the Government of the Chelyabinsk Region and the Government of the Kurgan Region, a world-class Ural interregional scientific and educational center is being created in the Chelyabinsk, Sverdlovsk and Kurgan regions. The activity of the Ural scientific and educational center involves combining the potential of leading scientific and educational organizations of higher education with organizations of the real sector of the economy that conduct research and development of a world level.

The result of this research and development is the receipt of new competitive technologies and products and their commercialization, the training of personnel to solve major scientific and technological problems in the priorities of scientific and technological development of the Chelyabinsk region.

Currently, the share of innovative enterprises and projects in the Chelyabinsk region is quite small, and is mainly represented by the classic industrial enterprises of metallurgy and mechanical engineering. It should also be noted that the indicators of the proportion of organizations implementing technological innovations and innovative activity of organizations show a downward trend. However, despite this, in the Chelyabinsk region, measures are actively being taken to develop scientific, technological and human potential. A model for the formation of an innovative climate in the region can be represented as follows (Figure 1) 


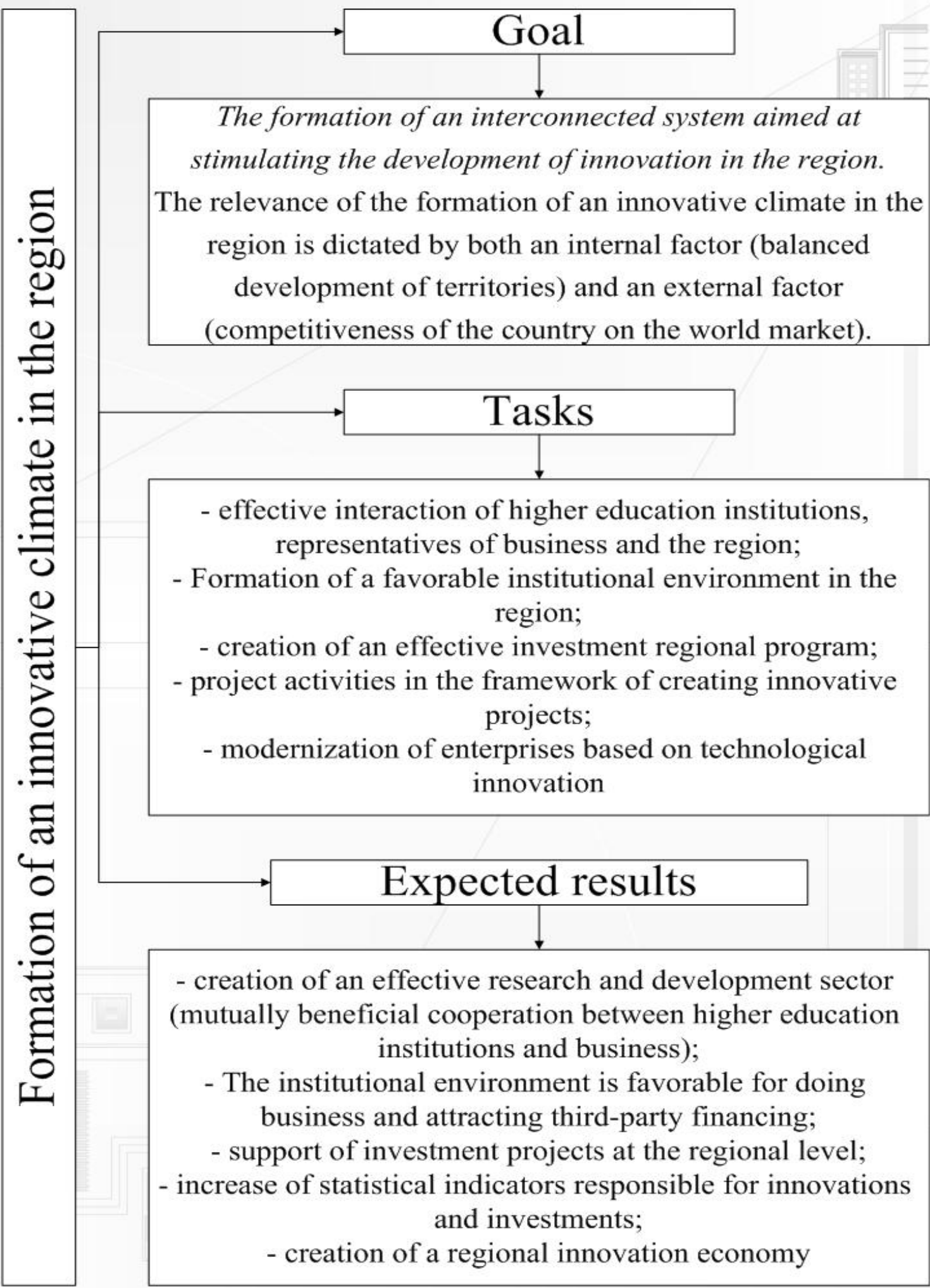

Figure 1 Implementation of measures aimed at creating an innovative climate in the region 
In this regard, in order to create an innovative climate in the Chelyabinsk region, in the investment and innovation direction it is necessary to ensure:

1. Improving the innovation climate in the region through the provision of services to investors in the course of providing investment activities.

2. Improving and ensuring an effective regional investment program to support organizations and private investors wishing to invest in the regional economy.

3. Review of the current legislative framework in the field of ensuring investment activity of the Chelyabinsk region.

4. Attraction of foreign capital in order to create new technological industries.

5. Creation of regional investment companies that would engage in project investment activities within the framework of regional targets and national projects.

6. Stimulation of innovative activity of organizations through tax incentives, the provision of favorable loans at reduced rates, information support and media coverage.

7. Creating an innovative climate in the region through the interaction of higher education institutions, business and representatives of regional authorities.

8. Effective implementation of regional programs in the direction of investment and innovative development.

9. Prevention of capital and brain drain abroad, by means of creating a comfortable business climate in the region.

\section{CONCLUSION}

This study continues the development of the author's concept of creating an innovative climate in the region. The study contributes to the theoretical focus of research on innovation in the regions, thereby complementing domestic and foreign experience in this area.

The analyzed state of the investment and innovation direction of the region's development leads to the idea that the development of innovations should be approached comprehensively and structurally. The authors proposed to consider the concept of the innovation climate in the region as a complex of a set of investment, institutional, and management measures that form an interconnected system aimed at stimulating the development of innovations in the region. The authors propose considering the approach to the formation of an innovative climate in the region through the following areas:

- $\quad$ investment direction;

- $\quad$ institutional direction;

- $\quad$ research direction;

- $\quad$ project direction.

In conclusion, proposals were made to ensure the formation of an innovative climate in the region. Future studies will focus on specific areas of the formation of this concept.

\section{REFERENCES}

[1] I.Yu. Shpurov, Industry 4.0, Expert Online. Moscow 2016. No. 40.

[2] D.M. Deryabin, Organizational and financial instruments to stimulate innovation, Space of Economics. 2010. No. 2-3.

[3] N.P. Ketova, V.N. Ovchinnikov, Strategy for the capitalization of innovative resources of the peripheral regions of Russia, taking into account their limitations,Space of Economics. 2014. No1.

[4] V.P. Kirpanev, Organizational and economic mechanism of the innovation and industrial policy of the region, Space of Economics. 2011. No. 2-3.

[5] E.I. Kushnikov, N.V. Pelikhov, Possibilities of innovative development of raw regions, Space of Economics. 2007. No. 3-2.

[6] O.N. Izyumova, Instrumentation for managing the innovative potential of a region in the context of its sustainable reproduction development (based on materials from the Volgograd region), Space of Economics. 2011. No. 4-3.

[7] V.G. Shelepov, Marketing tools for managing an innovative development strategy, Space of Economics. 2009. No. 4-2.

[8] I.M. Head, A.F. Sukhovey, Innovative and technological development of industrial regions in the conditions of socio-economic instability, Regional Economy. 2015. No1.

[9] S.O. Park, Regional innovation strategies in the knowledge-based economy. Geojournal. 2001; 53 (1): 2938. DOI: 10.1023 / A: 1015814611617

[10] A.G. Hu, Innovation and economic growth in East Asia: an overview. Asian Economic Policy Review. 2015; 10 (1): 19-37. DOI: 10.1111 / aepr.12078)

[11] U. Han, M. Asmild, M. Kunc, Regional R\&D efficiency in Korea from static and dynamic perspectives. Regional Studies. 2016; 50 (7): 1170-1184. DOI: 10.1080 / 00343404.2014 .984670

[12] S.N. Odai, The role of science, technology and innovative industries in national development. Determinants of National Development: Historical Perspectives and Implications for Developing Economies. 2015; pp. 215-230.

[13] F. Braudel, Material civilization, economics and capitalism, XV - XVIII centuries. T. 3. Time of the world. M., 1992. pp. 647-649.

[14] J. Schumpeter, Theory of Economic Development. M., 1982. pp. 174-177. 
[15] S. Kuznets, Modern economic growth: research and reflection. Nobel lecture, Nobel laureates in economics: a view from Russia. Ed. Yu.V. Yakovets. SPb .: Humanism, 2003

[16] B. A. Lundvall, National Systems of Innovation: Towards a Theory of Innovation and Interactive Learning. - L .: Pinter Publishers. 1992.

[17] S. Metcalfe, The Economic FoundaitionsofTecnology Policy: Equilibrium and Evolutionary Perspectives. In: Stoneman P. (ed.) Handbook of the Economics of Innovation and Technical Change. - London, Backwell. 1995.

[18] R. Nelson, National Innovation Systems. A Comperative Analysis. - Oxford: Oxford University Press. 1993.

[19] S. Freeman, The National System of Innovation in Historical Perspective, Cambridge Journal of Economics. 1995. Vol. 19. No. 1.

[20] M. Porter, International Competition, M.: International Relations, 1993

[21] S.G. Kochergin, Ways of innovative development of the region, Space of Economics. 2007. No. 1-2.

[22] N.N. Kiseleva, N.P. Ivanov, Assessing the level of innovative development of a region, Space of Economics. 2013. No. 2-2.

[23] V.V. Avilova, M.V. Egorova, A.I. Shinkevich, From the regional economy to the economy of innovation: continuity of tasks and promising areas of modern scientific economic research in the field of innovation development management, Bulletin of Kazan Technological University. 2010. No4.

[24] N.V. Beketov, Regional approaches to the formation of a national innovation system, Regional Economics: theory and practice. 2005. No. 10.

[25] A.M. Kalinin, A.N. Semenov, N.P. Belova, The essence of innovative potential and its role in the process of innovative development of the region, Bulletin of ChSU. 2011. No1.

[26] S. Yu. Glazyev, E.A. Naumov, A.A. Ponukalin, Concept 2020: regional innovation policy, RSM. 2012. No1.

[27] G.A. Khmeleva, Innovative processes in the regions of Russia, Bulletin of SamSU. 2014. No. 6 (117).

[28] N.E. Ivanova, Theoretical issues of innovative processes and their impact on the development of the economy of Russian regions, Space of Economics. 2011. No. 1-2.
[29] N.M. Tyukavkin, A.V. Badirova, On the mechanism of state regulation of the economy, Bulletin of Samara State University. 2011. No. 90. pp. 54-57.

[30] C. Henry, W. Vanhaverbeke, J. West, Open Innovation: Researching a New Paradigm. Oxford: Oxford University Press, 2006.

[31] P.M. Romer, Endogenous Technological Change. Journal of Political Economy, 1990, vol. 98, no. 5 (Part 2: The Problem of Development: A Conference on the Institute for the Study of Free Enterprise Systems), pp. 71102.

[32] O.A. Ischenko-Padukova, I.V. Movchan, Implementation of the socio-economic potential of regional policy in the context of innovative growth, Space of Economics. 2014. No. 2-3.

[33] V.R. Tkach, M.V. Tyulnina, Assessment of the innovative potential and innovative climate of an enterprise, GIAB. 2003. No4.

[34] E.P. Chentsova, E. M. Timofeeva, On the issue of managing the innovation climate of an organization, Bulletin of Eurasian Science. 2014. No6 (25).

[35] M.S. Volkova, The role of innovative behavior of subjects of the organization in the formation of an innovative climate, Gaudeamus. 2016. No2.

[36] I.V. Artyukhova, E.S. Zotikova, Components of the SWOT analysis matrix for assessing the innovative potential and the innovative climate of the organization, Innovation Science. 2016. No. 12-1.

[37] S. A. Tolstukhin, Role and components of the innovation climate in modern conditions // Statistics and Economics. 2012. No4.

[38] S. V. Terebova, A. M. Vyacheslavov, Innovative climate in the region: composition and development factors, Problems of development of the territory. 2011. No3.

[39] O.N. Sokolova, A.V. Kirillova, Assessment of the innovative climate of the region, Economics Profession Business. 2016. No. 2.

[40] E.A. Belyaeva, A systematic approach to managing the innovative climate of the region, Bulletin of the Academy of Knowledge. 2013. No1 (4).

[41] E.B. Akmaev, N. Sh. Epifanova, I.Yu. Petrova, The mechanism of the formation of an innovative climate in the region, Scientific and Technical Sheets of St. Petersburg State Polytechnic University. Economic sciences. 2010. No6 (112).

[42] I.G. Vidyaev, Innovation climate as a tool to stimulate the innovative development of the region, Vestnik TSPU. 2014. No8 (149). 
[47] Report on the state of competition in the Russian Federation for 2018 [Electronic resource], Website of the Federal Antimonopoly Service. URL: https://fas.gov.ru/documents/685117

[48] Development of innovative activities [Electronic resource], Website of the Ministry of Economic Development of the Chelyabinsk Region. URL: https://mineconom74.ru/razvitie-innovacionnoydeyatelnosti

[49] A.A. Egorova, A.O. Uzhegov, CREATING AN INNOVATIVE CLIMATE IN THE REGION USING A MODEL OF INTERACTION BETWEEN HIGHER EDUCATION INSTITUTIONS AND BUSINESS, Economic and Social Development: 50th International Scientific Conference on Economic and Social Development. Chelyabinsk, 13-14 February 2020 